\title{
Detection of human cytomegalovirus in motile spermatozoa and spermatogenic cells in testis organotypic culture
}

\author{
Victor A Naumenko ${ }^{1 *}$, Yurii A Tyulenev' ${ }^{1}$, Sergei A Yakovenko², Lubov' F Kurilo³ ${ }^{3}$ Ludmila V Shileyko, \\ Aleksander S Segal ${ }^{4}$, Larisa E Zavalishina ${ }^{5}$, Regina R Klimova', Anton S Tsibizov', Sergei V Alkhovskii ${ }^{1}$ and \\ Alla A Kushch ${ }^{1}$
}

\begin{abstract}
Background: The presence of human cytomegalovirus (HCMV) in male genital tract suggests its vertical transmission with spermatozoa and the development of a potentially dangerous fetal infection. The objective of the present study was to evaluate the possibility of intracellular HCMV localization in male germ cells and to examine the effect of the virus on human spermatogenesis.

Methods: Semen samples from 91 infertile and 47 fertile men were analyzed. HCMV was detected by real time $P C R$, rapid culture method and PCR in situ. Human testis organotypic culture and quantitative karyological analysis were used to investigate viral effects on spermatogenesis. Localization of HCMV in immature germ cells and spermatozoa was studied by immunostaining with monoclonal antibodies and ultrastructural analysis of infected organotypic culture.

Results: Viral DNA was detected in $12.3 \%$ samples of motile spermatozoa, while infectious activity only in $2.9 \%$ infertile and fertile men without statistically significant intergroup difference. According to PCR in situ, the mean percentage of infected cell in both groups was 1.5\% (0.25\%-15\%), which can serve as a criterion for evaluating the risk of HCMV transmission. In HCMV-infected organotypic culture viral antigens were identified in spermatides on day 4, in spermatogonia and spermatocytes on day 8, and in spermatozoa on day 14. Empty and full capsides and virions were visualized in germ cells by electron microscopy. The number of cells before introduction in culture was taken for 100\%. On day 14 infected culture contained 36.8\% spermatogonia, 18.7\% spermatocytes, $27.6 \%$ round spermatides and $42.5 \%$ elongated spermatides; in comparison with $82.2 \%, 51.5 \%$, $70.4 \%$ and $65.7 \%$ in uninfected culture, respectively (all $p<0.05$ ). There were no changes in the number and viability of spermatozoa.

Conclusions: HCMV was detected in male germ cells, both in sperm samples and in testis organotypic culture. The virus may infect immature germ cells which develop to mature HCMV-carrying spermatozoa. A considerable decrease in the number of immature germ cells indicates that HCMV produces a direct gametotoxic effect and can contribute to male infertility.
\end{abstract}

Keywords: human cytomegalovirus, infertility, spermatogenesis, testis organotypic culture

\footnotetext{
* Correspondence: virol8@mail.ru

'The D. I. Ivanovsky Institute of Virology, Ministry of Health and Social Development of the Russian Federation, 123098 Gamaleya str. 16, Moscow, Russia

Full list of author information is available at the end of the article
} 


\section{Background}

Male infertility accounts for $20-50 \%$ infertile couples and is often associated with genital infections [1]. Negative effects on reproductive function have been proposed for such viruses as the human immunodeficiency virus, human papillomavirus, herpes simplex virus, Epstein-Barr virus [1-4]. Human cytomegalovirus (HCMV) is widespread in human population and can be transmitted sexually. The effects of HCMV on spermatogenesis and its vertical transmission with sperm cells have not been investigated in sufficient detail due to the low detection rate of HCMV in semen - no more than $2.9 \%$ by the culture method $[5,6]$ and $1.4-8.7 \%$ by PCR $[5,7,8]$. At the same time Neofytou et al. have detected HCMV DNA by PCR in the semen of $56.9 \%$ asymptomatic fertile and infertile patients [9].

There is a controversy over the effects of HCMV on the major parameters of sperm quality - concentration, motility and morphology of gametes. A correlation between high concentration of HCMV in ejaculate and a transient decrease in the spermatozoa motility have been established [10], and the concentration of sperm cells has been found to decrease in patients with HCMV in semen [11]. However, the majority of researchers have found no HCMV effect on sperm quality $[3,7,12]$.

The issue of intragamete localization of HCMV is open to debate. The attempts to infect spermatozoa in vitro have been unsuccessful [13]. Investigation of interactions between HCMV and testicular cells is hampered by the possibility of autoimmune orchitis after biopsy. High species-specificity of HCMV impedes the investigation of processes occurring in human organism on animal models. In an attempt to overcome these difficulties we developed the model of HCMV infection in an organotypic culture of human testis. Using this model we demonstrated the possibility of intracellular HCMV localization in immature and mature male germ cells and HCMV influence on spermatogenesis.

\section{Materials and methods \\ Patients}

Semen samples were obtained from 138 men, including 91 infertile men (Group I) and 47 healthy donors enrolled in the sperm donor program (Group II). The informed consent was obtained from all patients.

\section{Clinical material}

Semen samples were fractionated by gradient centrifugation with SupraSperm reagent (Origio, Jyllinge, Denmark) according to the World Health Organization Laboratory Manual for the Examination and Processing of Human Semen (2010). The fraction of motile spermatozoa (MS) was washed two times in $2 \mathrm{ml}$ of Dulbecco modified Eagle Medium (DMEM; Paneko, Moscow, Russia) by centrifugation and used as described below.

\section{Virus and cell culture}

HCMV AD 169 strain was provided by the Russian Federation State Collection of Viruses. The virus was propagated and titrated in human embryo lung fibroblasts (HEF).

\section{Rapid culture method (RCM)}

RCM was used for detection of HCMV infectious activity in the samples. The material $(0.2 \mathrm{ml})$ was injected into each well of 24-well culture plate (Costar, Washington DC, USA) with HEF confluent monolayer, incubated for $1 \mathrm{~h}$ at $37^{\circ} \mathrm{C}$ in an atmosphere of $95 \%$ air $/ 5 \% \mathrm{CO}_{2}$. The cells were washed 2 times in serum-free culture medium, incubated for $48 \mathrm{~h}$ in $1 \mathrm{ml}$ of DMEM with $2 \%$ fetal calf serum (FCS; Gibco, Carlsbad, CA, USA), washed 2 times in PBS and fixed in cold methanol. HCMV was identified by immunoperoxidase staining with monoclonal antibody (Mab) against HCMV pp65 protein (DAKO, Glostrup, Denmark). Immunolabeled cells were calculated in an inverse light microscope LABOVEWRT FS (Leitz, Oberkochen, Germany).

HCMV DNA detection and quantification by real-time PCR HCMV DNA extraction was performed from $200 \mu \mathrm{l}$ of samples using QIAamp DNA mini kit (QIAGEN, Hilden, Germany) according to the manufacturer's protocol. In brief, $200 \mu \mathrm{l}$ of sample and $10 \mu \mathrm{l}$ of the STI-87 positive internal control (PIC; Interlabservice, Moscow, Russia) were added to $200 \mu \mathrm{l}$ of AL-buffer and heated at $56^{\circ} \mathrm{C}$ for $15 \mathrm{~min}$. $200 \mu \mathrm{l}$ of $96 \%$ ethanol was added, applied to columns and washed as per the manufacturer's instruction with the final elution in $200 \mu \mathrm{l}$ of the kit AE-buffer preheated to $50^{\circ} \mathrm{C}$. Real-time PCR was performed using the Amplisense CMV-screen/monitor-FL kit (Interlabservice) according to the manufacturer's protocol. Real-time amplification was carried out using $10 \mu \mathrm{l}$ DNA eluate combined with $10 \mu \mathrm{l}$ PCR-mix-1-FL and $5 \mu$ PCR-mix-2-FL using Rotor-Gene 6000 Instrument (Corbett Research, Doncaster, Australia) with the following cycling parameters: predenaturation at $95^{\circ} \mathrm{C}$ for $15 \mathrm{~min}, 95^{\circ} \mathrm{C}$ for $5 \mathrm{~s}, 60^{\circ} \mathrm{C}$ for 20 $\mathrm{s}$ and $72^{\circ} \mathrm{C}$ for $15 \mathrm{~s}$ for 45 cycles. Data acquisition was performed in both JOE/Yellow (for HCMV DNA) and ROX/ Orange (for the STI-87 PIC) channels during the annealing $\left(60^{\circ} \mathrm{C}\right)$ stage. For quantification of HCMV DNA two standard positive sample KSG1 $\left(10^{4}\right.$ copies per reaction mixture) and KGS2 $\left(10^{2}\right.$ copies per reaction mixture) (Interlabservice) were included in the run. Calculations of $C t$, preparation of standard curve and quantification of DNA in each sample were performed by Rotor-Gene Operating Software, version 1.8 (Corbett Research).

\section{PCR in situ}

Washed-off MS were transferred to glass slides, centrifuged for $5 \mathrm{~min}$ at $1500 \mathrm{rpm}$ in Cytospin 4 (Thermo 
Electron, Waltham, USA), air dried, fixed in 10\% formaldehyde for $4 \mathrm{~h}$ and washed twice in $0.05 \mathrm{M}$ Tris- $\mathrm{HCl}$. The preparations were then incubated with proteinase $\mathrm{K}$ (DAKO) for $30 \mathrm{~min}$ at $37^{\circ} \mathrm{C}$. Amplification with biotinilated primers (Gentech, Moscow, Russia) was carried out using T1 cycler (Biometra, Goettingen, Germany). Viral DNA was detected with the biotin-streptavidinperoxidase complex (DAKO) and diaminobenzidene (Sigma-Aldrich, St Louis, MO, USA). The proportion of sperm cells containing HCMV DNA was calculated after analysis of at least 2000 cells.

\section{Spermiological and quantitative karyological analysis}

Spermiological analysis was performed according to the World Health Organization Laboratory Manual for the Examination and Processing of Human Semen (2010). The immature germ cells (IGC) in sperm samples were identified by morphological criterions under a light microscope BX51 (Olympus, Tokyo, Japan). At least 200-300 IGC were calculated in each slide. The proportions of spermatids and primary spermatocytes at early stages (leptotene, zygotene, pachytene and diplotene) and cells that could not be identified (classified as unidentified and/or degenerated) were calculated as described previously [14].

\section{Organotypic culture of human testis explants}

The procedures followed were in accordance with ethical standards of the Helsinki Declaration and were approved by the local Ethics Committee of the D.I. Ivanovsky Institute of Virology of Ministry of Health and Social Development of Russian Federation; informed consent was obtained from all patients. Testis samples from 3 patients with prostate cancer $(62,65$ and 67 years old) were transported in fresh medium on ice immediately following orchidectomy. Testicular tissues were carefully dissected with scissors into $3 \mathrm{~mm}^{3}$ fragments. In each well of a six-well plate, two fragments were placed onto a permeable membrane insert (Falcon Labware, Mt Pritchard, NSW, Australia) and incubated at the interface between air and $2 \mathrm{ml}$ of DMEM with 10\% FCS (Gibco), $1 \mathrm{mmol} / \mathrm{l}$ sodium piruvate, $100 \mathrm{ng} / \mathrm{ml}$ vitamin $\mathrm{A}, 50 \mathrm{ng} / \mathrm{ml}$ vitamin $\mathrm{C}$ and $200 \mathrm{ng} / \mathrm{ml}$ vitamin $\mathrm{E}$ (all from Sigma-Aldrich), $4 \mathrm{mmol} / \mathrm{l}$ glutamine, $10 \mu \mathrm{g} / \mathrm{ml}$ insulin, $5 \mu \mathrm{g} / \mathrm{ml}$ transferrin and $50 \mu \mathrm{g} / \mathrm{ml}$ gentamycin (all from Paneko) at $37^{\circ} \mathrm{C}$ in an atmosphere of $95 \%$ air/ $5 \% \mathrm{CO}_{2}$. Culture medium was replaced every other day.

\section{HCMV-infection of testicular explants}

Fragments were incubated with $0.025 \mathrm{ml}$ of HCMV inoculate for $1 \mathrm{~h}$ at $37^{\circ} \mathrm{C}$. Multiplicity of infection (MOI) was 0.0001-0.001 plaque forming units (PFU) per cell. Control uninfected cultures were incubated in DMEM under the same conditions. Then explants were washed three times in $1 \mathrm{ml}$ DMEM and the culture was established for up to 14 days as described above. Viral load was estimated every other day in culture medium by PCR and RCM starting from Day 2. Three explants were analyzed in each point.

\section{Light microscopy}

For histological analysis, testicular explants $\left(3 \mathrm{~mm}^{3}\right)$ were fixed in neutral buffered $10 \%$ formaldehyde for 24 $\mathrm{h}$ at $4^{\circ} \mathrm{C}$, dehydrated in a series of graduated ethanol concentrations (70\%, 96\% and 100\%), embedded in paraffin, sectioned at $4.0 \mu \mathrm{m}$ and stained with Caracci's hematoxylin (BisVitrum, S.-Peterburg, Russia) for examination. The following morphological criteria were used for analysis of germ cells viability and explants architecture: cell number, cell size and location, signs of apoptosis, and histological characteristics of seminiferous tubules, including the basal membrane structure.

\section{Immunostaining}

To reveal HCMV proteins in the testis explants immunostaining with Mab to HCMV pp65 was performed on formaldehyde-fixed, paraffin-embedded tissues. Antigen retrieval was performed as follows: deparaffinized and dehydrated sections were treated for $20 \mathrm{~min}$ at $750 \mathrm{Wt}$ in microwave oven (Sanyo, Moriguchi, Osaka, Japan) in $10 \mathrm{mM}$ citrate buffer $(\mathrm{pH}=6.0, \mathrm{DAKO})$ and then washed in $0.05 \mathrm{~mol} / \mathrm{l}$ phosphate-buffer saline (PBS, $\mathrm{pH}$ 7.6; Gibco). Endogenous peroxidase was inactivated in deparaffinized sections by 5 -min treatment in PBS with $3 \% \mathrm{H}_{2} \mathrm{O}_{2}$. Slides were processed by PBS supplemented with $2 \%$ bovine serum albumin (BSA, Sigma-Aldrich) to block the non-specific sites, before overnight incubation at $4^{\circ} \mathrm{C}$ with the Mab to HCMV pp65 (0.02 ug/ml) (DAKO) diluted in PBS with 1\% BSA. Next steps were performed at room temperature. Reagents from UltraVision LP Large Volume Detection System kit (Thermo Scientific, Fremont, USA) were added according to the manufacturer's protocol after washing 4 times in PBS. The following substrate was used: $0.5 \mathrm{mg} / \mathrm{ml}$ diaminobenzidine (Sigma-Aldrich) in 0.05M TRIS-HCL, pH 8.0 with $3 \% \mathrm{H}_{2} \mathrm{O}_{2}$. Sections were prepared immediately after tissue dissection and on days 2, 4, 7 and 14 after introducing in culture. Stained cells were identified and photographed with a BX51 microscope coupled to a digital macro camera U-CMAD3 (Olympus).

\section{Transmission electron microscopy (TEM)}

TEM was performed immediately after tissue dissection and on days 2, 4, 7 and 14 of culturing. Two infected and two uninfected explants were analyzed in each point. The explants were fixed in $2.5 \%$ glutaraldehyde in $0.1 \mathrm{M}$ buffered sodium cacodylate ( $\mathrm{pH} 7.4$ ) for $24 \mathrm{~h}$ at $4^{\circ} \mathrm{C}$, postfixed in $1 \% \mathrm{OsO}_{4}$ in $0.1 \mathrm{M}$ sodium cacodylate 
buffer at room temperature for $40 \mathrm{~min}$, then dehydrated in gradual ethanol concentrations (70\%, 96\% and 100\%) and, subsequently, submitted to progressive impregnations in epon resin (Sigma-Aldrich). Polymerization was carried out at $60^{\circ} \mathrm{C}$ for $48 \mathrm{~h}$. Ultrathin sections were cut in an ultratome III (LKB, Bromma, Sweden), stained with uranyl acetate and lead citrate (Sigma-Aldrich) and examined in a JEM-100 S electron microscope (JEOL, Tokyo, Japan) at $80 \mathrm{kV}$.

\section{Statistics and data analysis}

The analysis was performed in StatXact 8 (Cytel, Cambridge, MA, USA) using Student's paired $t$-test, $\chi^{2}$ test and Mann-Whitney test. $\mathrm{P}<0.05$ was considered statistically significant.

\section{Results \\ HCMV detection in motile spermatozoa}

We have identified HCMV in the fraction of motile spermatozoa by several methods (Table 1). The frequency of HCMV DNA detection by PCR was higher than frequency of infectious activity by RCM $(p=0.006)$ but without significant differences between groups irrespective of method. The percentage of HCMV-infected cells determined by PCR in situ was $1.7 \%$ in average (maximum 15\%) among infertile men and $0.5 \%$ in average (maximum 5\%) among healthy men (Table 1 ). In spite of a 3-fold increase in the number of infected cells in Group I comparing with Group II, this difference was not significant $(\mathrm{p}>0.05)$.

\section{Spermiological and quantitative karyological analysis of HCMV-infected sperm}

According to the results of HCMV detection in sperm, all samples were divided into two groups: with and without HCMV infection. Each group included infertile patients and sperm donors. A comparative spermiological analysis

Table 1 Detection of HCMV in the fraction of motile spermatozoa

\begin{tabular}{|c|c|c|c|}
\hline \multirow[t]{2}{*}{ Patients } & \multicolumn{2}{|c|}{$\begin{array}{c}\text { Frequency of HCMV } \\
\text { detection by }\end{array}$} & \multirow{2}{*}{$\begin{array}{c}\text { Percentage of spermatozoa } \\
\text { containing HCMV DNA by } \\
\text { PCR in situ, median \% [min } \\
\text { max] }\end{array}$} \\
\hline & $\begin{array}{l}\text { rapid } \\
\text { culture } \\
\text { method }\end{array}$ & PCR & \\
\hline $\begin{array}{l}\text { Group I } \\
\text { (Infertile) }\end{array}$ & $3 / 91^{\mathrm{a}}(3.3 \%)$ & $10 / 91^{\mathrm{b}}(11 \%)$ & $1.7^{\mathrm{C}}[0.25 ; 15]$ \\
\hline $\begin{array}{l}\text { Group II } \\
\text { (Fertile) }\end{array}$ & $1 / 47^{\mathrm{a}}(2.1 \%)$ & $7 / 47^{b}(15 \%)$ & $0.5^{c}[0.35 ; 5]$ \\
\hline $\begin{array}{l}\text { Groups I } \\
\text { and II }\end{array}$ & $4 / 138(2.9 \%)$ & $17 / 138(12.3 \%)$ & $1.5[0.25 ; 15]$ \\
\hline
\end{tabular}

in these groups did not reveal any viral effect on the concentration of sperm cells $\left(50.6 \times 10^{6}\right.$ cells/ml vs. $69 \times 10^{6}$ cells $/ \mathrm{ml}, \mathrm{p}>0.05)$, the percentage of motile spermatozoa (20\% vs. $12.7 \%, \mathrm{p}>0.05$ ) and morphologically normal germ cells (9\% vs. 20\%, p > 0.05). Quantitative karyological investigation enabled us to assess viral effect on spermatogenesis without invasive intervention. The number of unidentified and/or degenerated germ cells in HCMVinfected semen samples was higher $(\mathrm{p}<0.05)$ while the population of spermatids was decreased ( $p<0.05)$ comparing with uninfected samples (Table 2).

\section{HCMV-infection of testis organotypic culture}

In order to study the effect of HCMV on spermatogenesis in more detail, we developed a model of HCMV infection in the human testis organotypic culture. It was demonstrated in preliminary experiments that general architecture of explants as well as viability of all germ cells preserved at least up to 14 days in culture.

Table 3 illustrates changes in HCMV markers which reflect the dynamics of viral infection. Due to high HCMV content in the inoculate $\left(4.2 \times 10^{8}\right.$ DNA copies/ $\mathrm{ml}$ ) the virus was not completely removed from the explants during washing procedure: after $12 \mathrm{~h}$ viral DNA content in the culture medium was $1.7 \times 10^{4}$ copies $/ \mathrm{ml}$. It gradually decreased within a 6 -day period and increased starting from Day 8, indicating HCMV replication in the culture. Infectious activity reached the maximum on Day 12, while DNA HCMV being accumulated up to Day 14.

\section{HCMV detection in testicular cells}

On Day 4, viral antigens were identified by immunostaining in the interstitial cells (fibroblasts and Leydig cells) and in individual spermatids. Foci of infection were located in the superficial layers of explants which contacted with viral inoculate. By Day 7 HCMV spread into deeper layers and infected spermatocytes and spermatogonia were revealed. On Day 14, we observed fibroblasts with typical features of HCMV-infection: enlarged nuclei and huge inclusion bodies in cytoplasm. At later stages of infection, typical HCMV pp65 staining was detected in spermatids, spermatocytes, spermatogonia (Day 7) and individual spermatozoa (Day 14). Figure 1 illustrates the presence of HCMV protein in spermatogonium adjacent to the basal membrane of the tubule and in two large round cells identified as spermatocytes. Immunohistochemical data were confirmed by electron microscopy. A great number of virions contained empty and full capsides and electron-dense bodies were identified in germ cells. Figure 2 shows the spermatogonium with capsids in the nucleus and virions with typical herpes-virus morphology in transport vacuole. 
Table 2 Analysis of immature germ cells population in the HCMV-infected sperm

\begin{tabular}{llccccc}
\hline Patients & \multicolumn{3}{c}{ Spermatocytes, median \% } & \multicolumn{2}{c}{ Spermatides, median \% } & Unidentified/degenerative cells, median \% \\
\cline { 2 - 5 } & Leptotene, zygotene & Pachytene & Diplotene & & $7.6^{\mathrm{b}}$ \\
\hline Uninfected $(\mathrm{n}=25)$ & 3.3 & 0 & 0.43 & $86.5^{\mathrm{a}}$ & $16.4^{\mathrm{b}}$ \\
\hline HCMV-infected $(n=20)$ & 2.9 & 0 & 0 & $78.3^{\mathrm{a}}$ & \\
\hline a, b- $p<0.05$ (Mann-Whitney test). & & & & &
\end{tabular}

\section{Decrease of the germ cells population in HCMV- infected testis explants}

The effect of HCMV on spermatogenesis was studied histologically by comparing of infected and uninfected testis explants at different time in culture. The results for germ cell populations on Days 7 and 14 are summarized in Table 4. It was shown that the number of spermatogonia, spermatocytes, round and elongated spermatids decreased considerably starting from Day 7 of infection. It should be noted that there were no changes in the number of spermatozoa. By Day 14, changes in immature cell population were more pronounced, reflecting gradual destruction in testicular architecture, loosening and vacuolization of germinative epithelium.

\section{Discussion}

The possibility of vertical transmission of herpes viruses with male gametes has been declared by several investigators $[15,16]$. In the first part of this work we studied intracellular HCMV localization in male gametes as a potential transmission vector of infection. HCMV DNA was found in $12.3 \%$ of sperm cells (mean for Groups I and II), and infectious virus - in $2.9 \%$ of all cases. The percentage of infected cells reached $15 \%$ in infertile patients and $5 \%$ in healthy donors, while the mean value in both groups was found to be $1.5 \%$.

There is no direct data concerning the correlation of HCMV infection of human spermatozoa and miscarriages and fetal maldevelopment. The results obtained in animal experiments are controversial. According to Neighbour et al. mouse CMV produced no effect on fertilization and embryogenesis in mice [16]. At the same time inhibition of blastocyst formation after infection of two-cell embryos with mouse CMV was observed [17]. There is evidence that herpes virus infection of males plays a role in fetal loss in goats [18]. Statistical analysis

Table 3 HCMV markers in human testis organotypic culture

\begin{tabular}{lccccccc}
\hline Method (viral load) & \multicolumn{7}{c}{ Days post infection } \\
\cline { 2 - 8 } & $\mathbf{2}$ & $\mathbf{4}$ & $\mathbf{6}$ & $\mathbf{8}$ & $\mathbf{1 0}$ & $\mathbf{1 2}$ & $\mathbf{1 4}$ \\
\hline RCM (PFU/ml) & nd $^{\mathrm{a}}$ & 0 & nd & 2,5 & nd & 60 & 22,5 \\
\hline PCR (DNA copies/ml) & 4730 & 3480 & 0 & 490 & 8600 & 8600 & 51900 \\
\hline${ }^{n}$ nd - not determined. & & & & & &
\end{tabular}

has been used to evaluate the role of herpes viruses in human reproduction. The frequency of herpes simplex virus detection in sperm samples of partners of women with repeated miscarriages was higher than in the control $(\mathrm{p}<0.05)$ [19]. A correlation between the presence of herpes viruses in ejaculate and negative outcome of pregnancy can be regarded as an indirect evidence for a vertical herpes virus transmission and associated pregnancy loss. The percentage of gametes carrying HCMV may serve as a criterion for estimation of the risk of vertical transmission of infection.

The ability of the virus to replicate in male germ cells was confirmed in the second part of the study using testis organotypic culture. Intensive viral accumulation occurred in the testicular interstitium, especially in fibroblasts where HCMV was detected starting from the Day 4 of infection. On Day 8, viral antigens were identified in spermatogonia and spermatocytes, and on Day 14 - in spermatozoa. Infection of germ cells was confirmed by electron microscopy.

Data obtained supposes that the presence of HCMV markers in the mature spermatozoa, which was demonstrated both in organotypic culture and in sperm samples, is a consequence of the precursor immature germ

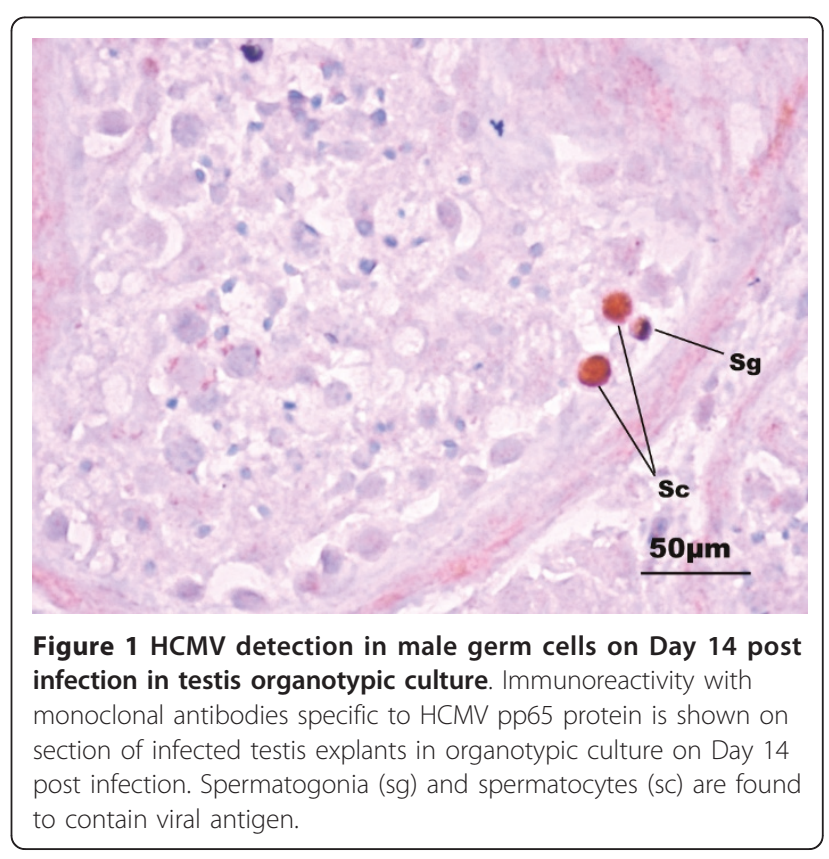



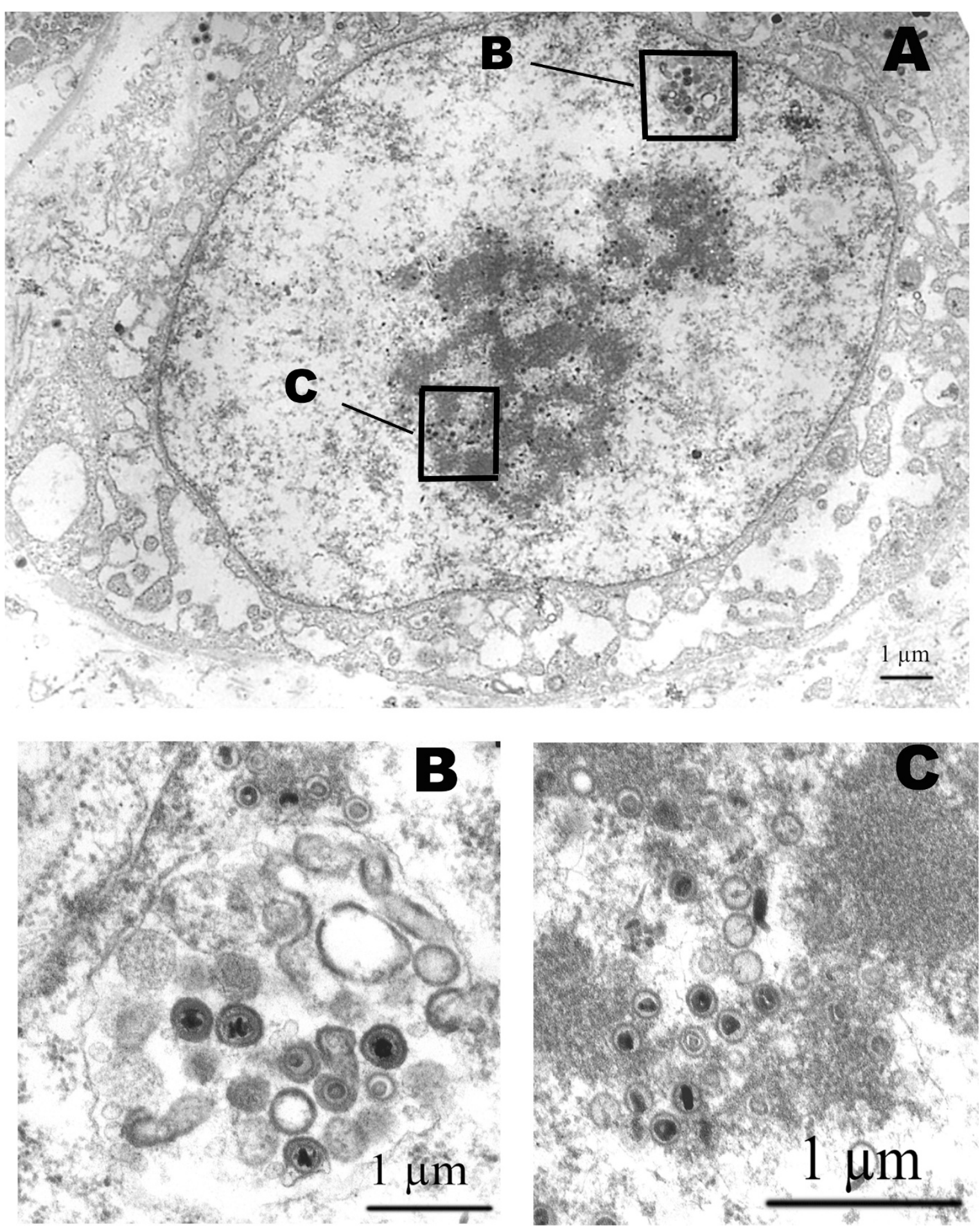

Figure $2 \mathrm{HCMV}$ in human spermatogonium on Day 14 post infection in testis organotypic culture. Ultrathin section was obtained from HCMV-infected testis explants in organotypic culture on Day 14 post infection (A). Full and empty viral capsids (insert B) and virions (insert C) were demonstrated in the nucleus of spermatogonium. 
Table 4 Quantitative analysis of immature and mature germ cells in HCMV-infected human testis organotypic culture

\begin{tabular}{|c|c|c|c|c|c|c|}
\hline \multirow[t]{3}{*}{ Germ cells } & \multicolumn{6}{|c|}{ Organotypic culture in vitro, days } \\
\hline & \multicolumn{3}{|c|}{7} & \multicolumn{3}{|c|}{14} \\
\hline & Uninfected & HCMV-infected & P-value & Uninfected & HCMV-infected & P-value \\
\hline Spermatogonia & $100^{a}$ & 53,8 & $<0.001^{\mathrm{b}}$ & 82,2 & 36,8 & $<0.001$ \\
\hline Spermatocytes & 100 & 38,9 & $<0.001$ & 51,5 & 18,7 & $<0.001$ \\
\hline Round spermatids & 104 & 37,7 & $<0.001$ & 70,4 & 27,6 & $<0.001$ \\
\hline Elongated spermatids & 96 & 57,7 & $<0.001$ & 65,7 & 42,5 & $<0.05$ \\
\hline Spermatozoa & 106,3 & 100 & $>0.05$ & 106,3 & 100 & $>0.05$ \\
\hline
\end{tabular}

a - mean quantity of cells, \%; quantity of cells before introduction in culture was taken for $100 \%$.

b - Student's paired t-test.

cells infection. In vivo it takes 14 days for the round spermatid differentiation into the spermatozoon [20], while in vitro this period was found to be much shorter $[21,22]$. These findings suggest that the presence of HCMV in spermatozoa at late stages of cultivation was due to differentiation of infected spermatids which had been already detected on the Day 4 of infection.

The association between HCMV infection and male infertility is discussed. In this work no difference between infertile and healthy men was found neither in the frequency of HCMV identification in sperm nor in the number of infected gametes. Routine semen analysis revealed no significant differences between infected and virus-free samples in concordance with previous reports $[7,12]$. Nevertheless quantitative karyological analysis demonstrated a decrease in the number of spermatids in sperm with simultaneous increase in number of unidentified/degenerated germ cells. These data correspond to the results of Moustafa et al. that the number of apoptotic cells is greater in sperm of infertile men in comparison with that of healthy donors [23]. Our results are also consistent with those of Wu et al. demonstrating an increase in number of apoptotic immature germ cells with chromatin pycnosis and vacuolation, damaged nuclear membrane, and apoptotic bodies in HCMVinfected semen samples [11].

Cultivation of testis explants in vitro allows one to examine the effects of various factors on spermatogenesis for at least two weeks. At the beginning of the second week post infection the following signs of viral replication were observed: the increase in viral DNA load and HCMV infectious activity with the spread of infection foci in the explants. The number of IGC decreased during the second week in vitro. This finding indicates that HCMV produces a specific lytic effect on germ cells at different stages of development, i.e., on spermatogonia, spermatocytes and spermatids.

The safety of spermatozoa population in infected culture raises the question of why HCMV has a deleterious effect on developing germ cells but not on mature cells. One of the possible explanations for such a difference is abortive HCMV infection of spermatozoa. This suggestion is supported by the fact that only empty capsids without electron-dense core (type A and type B) have been detected in mature sperm cells [24]. Our group and other researchers failed to identify filled capsids (type C) and enveloped virions into spermatozoa. By contrast, infected IGC contain all types of viral particles (Figure 2). A considerable loss of germ cells in an infected testis organotypic culture (Table 4) points to a lytic type of HCMV-infection in IGC. Current knowledge does not allow us to characterize exactly molecular mechanisms responsible for blocking HCMV morphogenesis in spermatozoa. One can suggest that the abortive nature of the infection is determined by the events occurring in a maturing gamete: 1) hypercondensation of chromatin with switching off majority of genes, including those that are necessary for viral replication; 2) loss of the cytoplasm with considerable part of replication machinery; 3) impaired nucleus-cytoplasm transport due to nuclear pore complex modification [25]. In sperm samples HCMV-infection of IGC resulted in decrease of spermatids and in increase of degenerative germ cells. At the same time neither concentration, nor sperm motility and morphology were found to be affected in infected sperm samples. We may suggest that in vivo the number of uninfected IGC is enough for producing a quantity of spermatozoa sufficient for fertilization. Moreover it should be noted that the major parameters of semen are highly variable in a population [26] and on the other hand, the frequency of HCMV detection and viral load in sperm is rather low. It means that a large group of patients would be required to reveal the HCMV effects on male fertility.

\section{Conclusions}

HCMV was found in male germ cells both in sperm samples and in testis organotypic culture infected in vitro. Data obtained suppose that HCMV infects immature germ cells that develop to mature HCMV-carrying spermatozoa. The significant decrease in immature germ cells upon viral infection indicates that HCMV produces 
a direct gametotoxic effect and can contribute in male infertility.

\begin{abstract}
Abbreviations
BSA: bovine serum albumin; DMEM: Dulbecco modified Eagle medium; FCS: fetal calf serum; HCMV: human cytomegalovirus; HEF: human embryo lung fibroblasts; IGC: immature germ cells; Mab: monoclonal antibody; MOI: multiplicity of infection; MS: motile spermatozoa; PBS: phosphate-buffered saline; PFU: plaque forming units; PIC: positive internal control; RCM: rapid cultural method; TEM: transmission electron microscopy.
\end{abstract}

\section{Acknowledgements}

We thank Prof. L'vov D.K. for general support; Gadgieva Z.S. and Chichev E.V. for technical assistance.

\section{Author details}

${ }^{1}$ The D. I. Ivanovsky Institute of Virology, Ministry of Health and Social Development of the Russian Federation, 123098 Gamaleya str. 16, Moscow, Russia. ${ }^{2}$ Altravita IVF Clinic, 117186 Nagornaya str. 4a, Moscow, Russia. ${ }^{3}$ Medical \& Genetic Research Center of Russian Academy of Medical Sciences, 115478 Moscworechye str. 1, Moscow, Russia. ${ }^{4}$ Department of Urology, Moscow State Medical Dental University, 127473 Delegatskaya str. 20/1, Moscow, Russia. ${ }^{5}$ P.A. Herzen Research Oncological Institute, 125284 2nd Botkinsky pr. 3, Moscow, Russia.

\section{Authors' contributions}

VAN performed the TEM, analyzed data and drafted the paper. YAT performed cultural work. SAY and ASS performed clinical investigation of sperm donors and infertile patients. LFK and LVS performed quantitative karyological investigation and morphological analysis of testis organotypic culture. LEZ performed immunostaining. RRK and SVA performed PCR in situ and PCR-rt. AAK designed the study, analyzed data and edited manuscript. All authors read and approved the final manuscript.

\section{Competing interests}

The authors declare that they have no competing interests.

Received: 11 April 2011 Accepted: 28 June 2011

Published: 28 June 2011

\section{References}

1. Kapranos N, Petrakou E, Anastasiadou C, Kotronias D: Detection of herpes simplex virus, cytomegalovirus, and Epstein-Barr virus in the semen of men attending an infertility clinic. Fertil Steril 2003, 79(Suppl 3):1566-1570.

2. Dejucq $N$, Jegou B: Viruses in the mammalian male genital tract and their effects on the reproductive system. Microbiol Mol Biol Rev 2001, 65:208-231.

3. Klimova RR, Chichev EV, Naumenko VA, Gadzhieva ZS, Tsibisov AS, Adieva AA, L'vov DK, Kurilo LF, Shileiko LV, Ostroumova TV, Sorokina TM, Gavrilov luA, Levchuk TN, lakovenko SA, Vasil'eva SG, Voznesenskaia luV, Simonenko Eiu, Kushch AA, Sukhikh GT: Herpes simplex virus and cytomegalovirus in male ejaculate: herpes simplex virus is more frequently encountered in idiopathic infertility and correlates with the reduction in sperm parameters. Vopr virusol 2010, 55:27-31.

4. Lai YM, Lee JF, Huang HY, Soong YK, Yang FP, Pao CC: The effect of human papillomavirus infection on sperm cell motility. Fertil Steril 1997, 67:1152-1155.

5. Bantel-Schaal U, Neumann-Haefelin D, Schleferstein G: Cytomegalovirus is absent from semen of a population of men seeking fertility evaluation. $J$ Infect Dis 1993, 168:518-519.

6. Levy R, Najioullah F, Keppi B, Thouvenot D, Bosshard S, Lornage J, Lina B, Guerin JF, Aymard M: Detection of cytomegalovirus in semen from a population of men seeking infertiliry evaluation. Fertil Steril 1997, 68:820-825.

7. Bezold G, Politch JA, Kiviat NB, Kuypers JM, Wolff H, Anderson DJ: Prevalence of sexually transmissible pathogens in semen from asymptomatic male infertility patients with and without leukocytospermia. Fertil Steril 2007, 87:1087-1097.
8. Bresson JL, Clavequin MC, Mazeron MC, Mengelle C, Scieux C, Segondy M, Houhou N: Risk of cytomegalovirus transmission by cryopreserved semen: a study of 635 semen samples from 231 donors. Hum Reprod 2003, 18:1881-1886.

9. Neofytou E, Sourvinos G, Asmarianaki M, Spandidos DA, Makrigiannakis A: Prevalence of human herpes virus types 1-7 in the semen of men attending an infertility clinic and correlation with semen parameters. Fertil Steril 2009, 91:2487-2494.

10. Lang DJ, Kummer JF, Hartley DP: Cytomegalovirus in semen. Persistence and demonstration in extracellular fluids. N Engl J Med 1974, 291:121-123.

11. Wu KH, Zhou QK, Huang JH, Lai RQ, Lin FH, Li B, Zhang CB, Zhou WN, Zhu ZP: Infection of cytomegalovirus and herpes simplex virus and morphology of the infected spermatogenic cells in infertile men. Zhonghua Nan Ke Xue 2007, 13:1075-1079.

12. Eggert-Kruse W, Reuland M, Johannsen W, Strowitzki T, Schlehofer JR: Cytomegalovirus (CMV) infection-Related to male and/or female infertility factors? Fertil Steril 2009, 91:67-82.

13. Pallier C, Tebourbi L, Chopineau-Proust S, Schoevaert D, Nordmann P, Testart J, Courtot AM: Herpesvirus, cytomegalovirus, human sperm and assisted fertilization. Hum Reprod 2002, 17:1281-1287.

14. Bocharova EN, Kurilo LF, Shileiko LV, Bragina EE, lurov YuB, Vorsanova SG, lurov lyu, Klimova RR, Kuchsh AA: Analysis of germ cell populations in ejaculate of men infected with herpes simplex virus. Ontogenez 2008, 39:47-57.

15. Baskar JF, Furnari B, Huang ES: Demonstration of developmental anomalies in mouse fetuses by transfer of murine cytomegalovirus DNAinjected eggs to surrogate mothers. J Infect Dis 1993, 167:1288-1295.

16. Neighbour PA, Fraser LR: Murine cytomegalovirus and fertility: potentional sexual transmission and effect of this virus on fertilization in vitro. Fertil Steril 1978, 30:216-222.

17. Heggie AD, Gaddis L: Effects of viral exposure of the two-cell mouse embryo on cleavage and blastocyst formation in vitro. Pediatr Res 1979, 13:937-941.

18. Uzal FA, Woods L, Stillian M, Nordhausen R, Read DH, Van Campen $H_{\text {, }}$ Odani J, Hietala S, Hurley EJ, Vickers ML, Gard SM: Abortion and ulcerative posthitis associated with caprine herpesvirus-1 infection in goats in California. J Vet Diagn Invest 2004, 16:478-484.

19. Bocharova EN, Zavalishina LE, Bragina EE, Klimova RR, Gusak YK, Kurilo LF, Shileiko LV, Petrov AN, Frank GA, Kushch AA: Detection of herpes simplex virus genomic DNA in spermatozoa of patients with fertility disorders by in situ hybridization. Dokl Biol Sci 2007, 412:82-86.

20. Heller CG, Clermont $Y$ : Kinetics of the germinal epithelium in man. Recent Progr Horm Res 1964, 20:545-575.

21. Cremades N, Bernabeu R, Barros A, Sousa M: In vitro maturation of round spermatids using coculture on Vero cells. Hum Reprod 1999, 14:1287-1293.

22. Tesarik J, Greco E, Rienzi L, Ubaldi F, Guido M, Cohen-Bacrie P, Mendoza C: Differentiation of spermatogenic cells during in vitro culture of testicular biopsy samples from patients with obstructive azoospermia: effect of recombinant follicle stimulating hormone. Hum Reprod 1998, 13:2772-2781.

23. Moustafa MH, Sharma RK, Thornton J, Mascha E, Abdel-Hafez MA, Thomas AJ, Agarwal A: Relationship between ROS production, apoptosis and DNA denaturation in spermatozoa from patients examined for infertility. Hum Reprod 2004, 19:129-138.

24. Bocharova EN, Abdumalikov RA, Bragina EE, Klimova RR, Adueva SM, Medzhidova MG, Kurilo LF, Kushch AA: Determination of the proteins and capsids of herpes simplex virus in human spermatozoa. Dokl Biol Sci 2003, 391:379-383.

25. Hermo L, Pelletier R-M, Cyr DG, Smith CE: Surfing the wave, cycle, life history, and genes/proteins expressed by testicular germ cells. Part 4: intercellular bridges, mitochondria, nuclear envelope, apoptosis, ubiquitination, membrane/voltage-gated channels, methylation/ acetylation, and transcription factors. Microsc Res Tech 2010, 73(4):364-408.

26. Keel BA: Within- and between-subject variation in semen parameters in infertile men and normal semen donors. Fertil Steril 2006, 85:128-134.

doi:10.1186/2042-4280-2-7

Cite this article as: Naumenko et al:: Detection of human cytomegalovirus in motile spermatozoa and spermatogenic cells in testis organotypic culture. Herpesviridae 2011 2:7. 